\title{
Upaya Pemerintahan Kabupaten Bima Dalam Melibatkan Masyarakat Membangun Wisata Lariti Di Kecamatan Sape Kabupaten Bima (Studi Kasus Pada Dinas Pariwisata Kabupaten Bima)
}

Mustamin H. Idris ${ }^{1}$, Nidya Putri Syahida ${ }^{2}$, Andi Ardyansyah ${ }^{3}$

${ }^{1}$ Prodi Administrasi Publik, Universitas Muhammadiyah Mataram , Indonesia

${ }^{2}$ Prodi Administrasi Bisnis, Universitas Muhammadiyah Mataram, Indonesia

${ }^{3}$ Prodi Administrasi Publik, Universitas Muhammadiyah Mataram, Indonesia

\section{INFO ARTIKEL}

Riwayat Artikel:

Diterima: 15-07-2018

Disetujui: 16-07-2018

\section{Kata Kunci: \\ 1. Upaya \\ 2. Pemerintahan \\ 3. Melibatkan \\ 4. Masyarakat \\ 5. Wisata Lariti}

\section{ABSTRAK}

Abstrak: Pariwisata merupakan salah satu sektor yang sangat diandalkan dalam pembangunan nasional, Pariwisata juga berperan dalam menciptakan lapangan kerja dan mengurangi pengangguran. Hal ini dibuktikan dengan kontribusi sektor pariwisata terhadap tenaga kerja pada tahun 201512,1 juta orang atau 10,6\% dari total tenaga kerja nasional, untuk mendukung sektor pariwisata diperlukan adanya partisipasi dari masyarakat dan keprofesionalan dari pemerintah dalam memberi kebijakan pembangunan sektor pariwisata sesuai dengan peraturan dan ketetapan pemerintah pada Undang-undang RI Nomor 10 Tahun 2009 tentang kepariwisataan. Berangkat dari kondisi tersebut maka peneliti berusaha menganalisis upaya Pemerintahan Kabupaten Bima dalam melibatkan masyarakat membangun wisata Lariti di Kecamatan Sape Kabupaten Bima.

Adapun tujuan dari penelitian ini, untuk mengetahui upaya Pemerintah Kabupaten Bima dalam melibatkan masyarakat untuk membangun wisata Lariti, beserta faktor yang menjadi pendukung dan penghambat Pemerintah Kabupaten Bima dalam upaya melibatkan masyarakat untuk membangun wisata Lariti, maka metode yang digunakan dalam penelitian ini adalah metode deskriptif kualitatif dengan teknik pengumpulan data menggunakan wawancara dan dokumentasi.

Hasil penelitian menunjukan bahwa upaya Pemerintah Kabupaten Bima dalam melibatkan masyarakat membangun wisata Lariti di Kecamatan Sape berada pada nilai positif, hal ini menunjukan bahwa secara kualitatif Pemerintah Kabupaten Bima melalui Dinas Pariwisata dan Kebudayaan Kabupaten Bima melibatkan masyarakat secara aktif dalam pembangunan wisata Lariti, selain itu perilaku masyarakat dan infrastruktur Lariti menjadi faktor pendukung dan penghambat Pemerintah Kabupaten Bima dalam melibatkan masyarakat untuk membangun wisata Lariti di Kecamatan Sape Kabupaten Bima.

\section{Abstract}

Tourism is one of the most reliable sectors in national development, tourism also plays a role in creating employment and reducing unemployment. This is evidenced by the contribution of the tourism sector to the workforce in 201512.1 million people or $10.6 \%$ of the total 


Keyword:
1. Effort
2. Government
3. Engaging
4. Society
5. Lariti Tourism

\section{Latar Belakang}

Pariwisata merupakan salah satu sektor yang sangat diandalkan dalam pembangunan nasional karena pariwisata dapat meningkatkan pendapatan nasional dan pendapatan daerah serta devisa negara (Peraturan Mentri Pariwisata No 8 Tahun 2017) tentang pendapatan Nasional dan pendapatan Daerah. Pariwisata juga berperan dalam menciptakan lapangan kerja dan mengurangi pengangguran hal ini dibuktikan dengan kontribusi sector pariwisata terhadap tenaga kerja pada tahun 2010 menyumbang 4 juta orang menjadi 12,1 juta orang pada tahun 2015 atau $10,6 \%$ dari total tenaga kerja nasional sekaligus menciptakan kesejahteraan masyarakat.

Dalam realitanya, sektor pariwisata dijadikan sebagai alat untuk menormalkan kembali ekonomi Indonesia yang kurang stabil. Untuk mendukung sektor pariwisata, maka diperlukan adanya partisipasi dari masyarakat dan keprofesionalan dari pemerintah dalam memberi kebijakan pembangunan sektor pariwisata itu sesuai dengan peraturan dan ketetapan pemerintah pada Undang-undang RI Nomor 10 Tahun 2009 tentang kepariwisataan. Di samping itu dengan adanya perhatian yang serius dari pemerintah terhadap pembangunan pariwisata, maka usaha di bidang kepariwisataan di Indonesia diharapkan berkembang dengan baik.

Menurut peraturan Mentri Kebudayaan dan Pariwisata Tahun 2004, Indonesia yang merupakan negara kepulauan terbesar di dunia yang terdiri dari lebih 17.000 pulau dan memiliki panjang garis pantai $81.000 \mathrm{~km}$ yang merupakan terpanjang kedua di dunia setelah Kanada peraturan Mentri Pariwisata Tahun 2015 No 545 tentang luas wilayah perairan Indonesia. Tidak heran Indonesia memiliki begitu banyak wilayah pantai dengan pasir putih yang luas dan menjadi objek wisata. Salah satunya Nusa Tenggara Barat yang merupakan sektor kepulauan yang terbagi menjadi 2 kawasan pulau besar yaitu, pulau Lombok dan Sumbawa, yang memiliki destinasidestinasi pariwisata potensial, seperti Pantai Senggigi, Gili Trawangan, Gili Air, Pantai Kuta dan Pantai Lariti yang berada di Kabupaten Bima Kecamatan Sape.

Objek wisata pantai Lariti di Kecamatan Sape Kabupaten Bima sangat potensial dengan daya tarik wisata berupa air laut yang terbelah serta di dukung oleh infrastruktur jalan, masyarakatnya yang ramah dan letak geografis Kecamatan Sape yang strategis sebagai wilayah pelabuhan penyebrangan serta dengan kondisi 
alam yang masih alami akan sangat memungkinkan pariwisata untuk berkembang pesat. Oleh sebab itu wisata Pantai Lariti bisa di kembangkan menjadi objek wisata unggulan dan daya tarik wisata di Kabupaten Bima khususnya di Kecamatan Sape. Begitu besar potensi objek wisata lariti apabila di kembangkan secara profesional akan sangat memungkinkan jika Kabupaten Bima menjadi primadona kunjungan wisatawan baik secara lokal, regional, nasional maupun internasional.

Dukungan dan peran pemerintah adalah faktor penting dalam membangun pariwisata terutama di daerah, pariwisata di Indonesia begitu beragam, baik itu budaya, alam, flora dan fauna akan tetapi sebagian besar masih belum terekspos dan terjangkau oleh wisatawan, hal ini disebabkan karena tidak adanya startegi pemerintah untuk menarik wisatawan.

Menurut Suryono ( 2004:80 ) strategi pada prinsipnya berkaitan dengan persoalan : kebijakan pelaksanaan, penentuan tujuan yang ingin di capai penggunaan sarana dan prasarana. Oleh karena itu, strategi juga harus mendukung oleh kemampuan untuk mengantisipasi kesempatan yang ada. Dalam melaksanakan fungsi pembangunan pariwisata daerah, pemerintah harus benar-benar melakukan berbagai upaya nyata sebagai cara untuk mendorong pembangunan pariwisata daerah.

Sedangkan menurut Damanik dan Weber (2006:26) mengartikan pembanguana pariwisata "sebagai upaya pembangunan sumber daya manusia (atraksi, aksibilitas, dan amnesitas), pariwisata yang bertujan untuk memberikan keuntungan optimal bagi pemangku kepentingan (Stakehoulders) dan nilai kepuasan optimal bagi wisatawan".

Dalam pembangunan pariwisata perlu ditingkatkan secara terarah dan terpadu terutama mengenai pendidikan dan perencanaan pengembangan fisik. Kedua hal tersebut hendaknya saling terkait sehingga pengembangan tersebut menjadi realistis dan proposional. Agar objek wisata pantai lariti dapat dijadikan sebagai objek wisata yang menarik, maka factor yang sangat menunjang yang harus dibangun oleh pemerintah Kabupaten Bima adalah, penyediaan sarana dan prasarana sehingga objek kepariwisataan lariti menjadi suatu objek yang menyedot banyak pengunjung dan kelak akan berguna juga untuk meningkatkan ekonomi baik untuk komunitas disekitar objek pariwisatalariti maupun pemerintah daerah.

Jadi tidak heran lagi sering mendengarkan tuntutan pembangunan sering ditujukan kepada pemerintah dan dinas pariwisata, menyangkut pembangunan objek wisata lariti yang harusnya bisa dikembangkan menjadi salah satu objek wisata yang potensial.Tidak seriusnya pemerintah daerah khususnya dinas pariwisata Kabupaten Bima dalam upaya membangun dan mengembangkan objek wisata lariti, memunculkan satu pertannyaan yaitu bagaimana upaya pemerintah Kabupaten Bima dalam melibatkan masyarakat untuk membangun objek pariwisata lariti.

Berdasarkan uraian diatas, maka penting kirannya penelitian ini dilakukan untuk mengetahui bagaimana upaya pemerintah kabupaten bima dalam melibatkan masyarakat untuk membangun objek pariwisata lariti di Kecamatan Sape Kabupaten Bima.

\section{Tinjauan Pustaka}

\section{a. Administrasi Publik}

Definisi Administrasi Publik menurut Chandler dan Plano dalam Pasolong, Harbani (2011:7), mengatakan bahwa Administrasi Publik adalah proses dimana Sumber Daya dan personel Publik diorganisir dan dikoordinasikan untuk memformulasikan, mengimplementasikan, dan mengelola (manage) keputusan-keputusan dalam Kebijakan Publik. Konsep Administrasi Publik di Indonesia pada dasarnya bukanlah konsep yang baru, karena konsep administrasi Publik sudah ada sejak dari dulu, hanya para pakar yang mengganti istilah Administrasi Publik menjadi Administrasi Negara. Begitu pula buku-buku asing misalnya yang berjudul "Public Adminitration" diganti menjadi Administrasi Negara. Jika ada para pakar yang mengatakan bahwa Administrasi Negara perlu direformasi menjadi Administrasi Publik, maka itu dapat dikatakan kesalahan berfikir, karena Administrasi Publik sudah ada sejak dari dulu. (Pasolong, 2012:55).

Chandler \& Plano dalam Pasolong (2012:55), menjelaskan bahwa Administrasi Publik merupakan Seni dan Ilmu yang ditujukan untuk mengatur "Publik Affairs" dan melaksanakan berbagai tugas yang ditentukan. Administrasi Publik sebagai disiplin ilmu bertujuan untuk memecahkan Masalah Publik melalui perbaikan-perbaikan 
terutama dibidang organisasi, sumberdaya manusia dan keuangan. Menurut Nicholas Hendry dalam Pasolong (2012:56) mendefinisikan "Administrasi Publik adalah suatu kombinasi yang kompleks antara teori dan praktik, dengan tujuan mempromosikan pemahaman terhadap pemerintah dalam hubungannya dengan masyarakat yang diperintah, dan juga mendorong kebijakan publik agar lebih responsif terhadap kebutuhan sosial".

George J. Gordo dalam Inu Kencana, (51:2015) Administrasi Publik dapat dirumuskan sebagai seluruh proses yang baik yang dilakukan organisasi maupun perseorangan yang berkaitan dengan penerapan atau pelaksanaan hukum dan peraturan yang dikeluarkan oleh badan legislatif, eksekutif serta peradilan. Administrasi Publik dimaksudkan untuk lebih memahami hubungan pemerintah dengan publik serta meningkatkan responbilitas kebijakan terhadap berbagai kebutuhan publik, dan juga melembagakan praktik-praktik manajerial agar terbiasa melaksanakan suatu kegiatan dengan efektif, efisien dan rasional.

Beberapa definisi Administrasi Publik yang telah dikemukakan oleh para ahli di atas, dapat dipahami bahwa Administrasi Publik adalah kerjasama yang dilakukan oleh sekelompok orang atau lembaga dalam melaksanakan tugas-tugas pemerintahan dalam memenuhi kebutuhan publik secara efesien dan efektif.

\section{b. Partisipasi Masyarakat}

Partisipasi berasal dari bahasa Inggris yaitu "Participation" menurut Echols \& Shadily (dalam Soetrisno, 2000: 419) yaitu "suatu kegiatan untuk membangkitkan perasaan dan diikut sertakan atau ambil bagian dalam kegiatan suatu organisasi". Sedangkan menurut Davis (2000:142) partisipasi adalah "keterlibatan mental dan emosional seseorang/individu dalam situasi kelompok yang mendorong dia untuk berkontribusi terhadap tujuan kelompok dan mempertanggungjawabkan

keterlibatannya".Menurut

Sumaryadi

(2005:46) partisipasi berarti "peran serta seseorang atau kelompok masyarakat dalam proses pembangunan baik dalam bentuk pernyataan maupun dalam bentuk kegiatan dengan memberi masukan pikiran, tenaga, waktu, keahlian, modal atau materi, serta ikut memanfaatkan dan menikmati hasil-hasil pembangunan". Dengan maksud dan tujuan yang agar masyarakat dapat menjaga hasil dari pembangunan karena merasa bahwa pembangunan itu juga milik mereka karena telah dilibatkan dalam program tersebut.

Partisipasi menurut Effendi (Siti Irene A.D2011:58) terbagi menjadi 2 yaitu, partisipasi vertikal danpartisipasi horizontal. Disebut partisipasi vertikal "karena terjadi dalambentuk kondisi tertentu masyarakat terlibat atau mengambil bagian dalamsuatu program pihak lain, dalam hubungan di mana masyarakat beradasebagai status bawahan, pengikut atau klien", sedangkan partisipasihorizontal "masyarakat mempunyai prakarsa dimana setiap anggota ataukelompok masyarakat berpartisipasi horizontal satu dengan yang lainnya.Partisipasi semacam ini merupakan tanda permulaan tumbuhnya masyarakatyang mampu berkembang secara mandiri".

Dari pendapat-pendapat di atas dapat disimpulkan bahwa keterlibatan masyarakat secara langsung dalam proses pembangunan merupakan langkah awal untuk keberhasilan suatu pembangunan, dalam pelaksanaan pembangunan harus ada sebuah rangsangan dari pemerintah supaya masyarakat dalam keikutsertaannya memiliki suatu motivasi.Seperti pendapat Mukerji (dalam Bhattacharyya, 1972:21) dimana "partisipasi masyarakat dapat ditingkatkan dengan memberi perangsang kepada masyarakat".Menurut McKeachie dan Doyle (dalam Jayadinata, 2000:26) masyarakat adalah "sekelompok manusia yang bergantung satu sama lain dan yang telah memperkembangkan pola organisasi yang memungkinkan mereka hidup bersama dan dapat mempertahankan diri sebagai kelompok". Masyarakat terkecil adalah keluarga, masyarakat yang lebih besar adalah suku bangsa dan negara, dan masyarakat terbesar adalah seluruh umat manusia.

Menurut Simatupang (dalam Yuwono, 2001:124) memberikan beberapa rincian tentang pengertian partisipasi sebagai berikut :

1. Partisipasi berarti apa yang kita jalankan adalah bagian dari usaha bersama yang dijalankan bahu-membahu dengan saudara kita sebangsa dan setanah air untuk membangun masa depan bersama. 
2. Partisipasi berarti pula sebagai kerja untuk mencapai tujuan bersama diantara semua warga negara yang mempunyai latar belakang kepercayaan yang beraneka ragam dalam negara pancasila kita, atau dasar hak dan kewajiban yang sama untuk memberikan sumbangan demi terbinanya masa depan yang baru dari bangsa kita.

3. Partisipasi tidak hanya berarti mengambil bagian dalam pelaksanaan-pelaksanaan, perencanaan pembangunan. Partisipasi berarti memberikan sumbangan agar dalam pengertian kita mengenai pembangunan kita nilai-nilai kemanusiaan dan cita-cita mengenai keadilan sosial tetap dijunjung tinggi.

4. Partisipasi dalam pembangunan berarti mendorong ke arah pembangunan yang serasi dengan martabat manusia. Keadilan sosial dan keadilan Nasional dan yang memelihara alam sebagai lingkungan hidup manusia juga untuk generasi yang akan datang.

\section{c. Pembangunan Pariwisata}

Pembangunan dapat diartikan berbedabeda oleh setiap orang tergantung dari sudut pandang apa yang digunakan oleh orang tersebut. Perbedaan cara pandang mengenai proses pembangunan yang dilakukan akan menyulitkan kepada kita tentang seberapa maju proses pembangunan yang dilakukan di sebuah negara atau daerah. Menurut Galtung (Dalam Trijono, 2007:3)" Pembangunan merupakan upaya untuk memenuhan kebutuhan dasar manusia, baik secara individual maupun kelompok, dengan cara-cara yang tidak menimbulkan kerusaka, baik terhadap kehidupan sosial maupun lingkungan alam". Pembangunan tersebut dapat merupakan pembangunan fisik dan dapat merupakan pembangunan sosial ekonomi, sedangkan pembangunan regional meliputi suatu wilayah dan mempunyai tekanan utama pada perekonomian dan tekanan berikutnya pada keadaan fisik, sehingga merupakan gabungan dari kedua hal tersebut diatas,dan pembangunan dapat dikelompokan menjadi 3 bagian yang saling berhubungan yaitu:

1. Menimbulkan peningkatan kemakmuran dan peningkatan pendapatan serta kesejahteraan sebagai tujuan, dengan tekanan perhatian pada lapisan terbesar (dengan pendapatan terkecil) dalam masyarakat.

2. Memilih metode yang sesuai untuk mencapai tujuan tersebut.

3. Menyusun kembali (restructuring) masyarakat dengan maksud supaya timbul pertumbuhan sosial ekonomi yang kuat.

Menurut Siagian (2005:9) pembangunan adalah "suatu usaha pertumbuhan dan perubahan yang berencana dan dilakukan secara sadar oleh suatu bangsa, negara, dan pemerintah menuju modernitas dalam rangka pembinaan bangsa". Pada dasarnya dalam negara berkembang yang lepas landas dari suatu keadaan taraf rendah menuju taraf yang tinggi yaitu modernisasi, dimana variablevariabel dalam pembangunan dapat mengalami perubahan kearah yang lebih baik. Oleh sebab itu dibutuhkan inisiatif, aktif, dan kritis bagi setiap warga negaranya untuk dapat bertindak dengan arah yang tepat dan dengan mampu menjadikan sumber-sumber dalam pembuatan keputusan oleh pemerintah dalam pembangunan.Menurut Katz (1991) pembangunan pada prinsipnya adalah "merupakan suatu proses perubahan pokok pada masyarakat dari suatu keadaan nasional tertentu menuju keadaan nasional lain yang dianggap lebih bernilai", sedangkan menurut Philip Roup (1993) "pembangunan sabagai proses perubahan dengan tanda-tanda dari suatu keadaan nasiaonal yang dianggap kursng dikehendaki menuju ke suatu keadaan nasional tertentu yang dinilai lebih dikehendaki".

Menurut Syamsi Yuswar Zainul Basri \& Mulyadi Subri (2006:15) "pembangunan adalah proses perubahan sistem yang di rencanakan kearahperbaikan yangorientasinya pada modernis pembangunan dan kemajuansosial ekonomis". Menurut Bryant dan White (1987: 13 mendefiniskan "Pembangunan adalah upaya untuk meningkatkan kemampuan manusia dalammempengaruhi masa depannya". Menurut Bryant dan White ada 5 implikasi dari definisi tersebut yaitu :

1. Pembangunan berarti membangkitkan kemampuan optimal manusia, baik individu maupun kelompok.

2. Pembangunan berarti mendorong timbulnya kebersamaan, kemerataan dan kesejahteraan. 
3. Pembangunan berarti mendorong dan menaruh kepercayaan untuk membimbing dirinya sendiri sesuai dengan kemampuan yang ada padanya kepercayaan ini dinyatakan dalam bentuk kesempatan yang sama, kebebasan memilih dan kekuasaan memutuskan.

4. Pembangunan berarti mengurangi ketergantungan Negara yang satu dengan Negara lain dan menciptakan hubungan saling menguntungkan dan dihormati.

Menurut Undang-undang No25

Tahun 2004 tentang Sistem Perencanaan Pembangunan Nasional Pasal 1 ayat 3, Sistem Perencanaan Pembangunan Nasional adalah kesatuan tata cara perencanaan pembangunan untuk menghasilkan rencana - rencana pembangunan dalam jangka panjang, jangka menengah, dan tahunan yang dilaksanakan oleh unsur penyelenggara Negara dan masyarakat di tingkat Pusat dan Daerah. Menurut Tjokroamidjojo (1990) Perencanaan Pembangunan dapat dilihat pembedanya dari segi jangka waktu rencana, yaitu :

1. Rencana jangka panjang, perencanaan ini meliputi jangka waktu 10 tahun keatas.

2. Rencana jangka menengah, perencanaan ini meliputi jangka waktu antara 3 sampai dengan 8 tahun.

3. Rencana jangka pendek, perencanaan dengan jangka waktu setengah sampai dengan 2 tahun.

Secara sederhana, keterlibatan merupakan sebuah proses dimana masyarakat sebagai stakeholders, terlibat mempengaruhi dan mengendalikan pembangunan di tempat mereka masing-masing. Berdasarkan pendapat Mikkelsendalam (Puspitasari, 2014:124-125), terkait beberapa poin pengertian keterlibatan masyarakat bersama pemerintah dalam membangun wisata, dapat dipahami bahwa keterlibatan ada pada motif sukarela, adanya penyertaan pikiran dan emosi, adanya kepekaan dan adaptasi secara aktif untuk memunculkan komunikasi antar para pihak yang terlibat dalam aktivitas pelibatan masyarakat. Keterlibatan pada praktiknya memungkinkan warga masyarakat untuk terlibat dalam berbagai ajang yang mempengaruhi kehidupannya sehingga mereka juga memiliki akses terhadap sumber daya maupun institusi.
Menurut Cohen dan Uphoff (1979, dalam (Dwiningrum, 2011:61-62) keterlibatan yang dilakukan masyarakat bersama pemerintah dalam membangun wisata dapat dilihat mulai dari tahap:

1. Keterlibatan dalam pengambilan keputusan: Keterlibatan dalam hal pengambilan keputusan ini sangat penting, karena masyarakat dituntut untuk ikut menentukan arah dan orientasi pembanguanan.

2. Keterlibatan dalam pelaksanaan; ruang lingkup keterlibatan dalam pelaksanaan suatu program meliputi, menggerakan sumber daya dan dana, kegiatan administrasi dan koordinasi, serta penjabaran program.

3. Terlibat dalam pengambilan manfaat; keterlibatan ini tidak terlepas dari kualitas maupun kuantitas dari hasil pelaksanaan program yang bisa dicapai. Dari segi kualitas, keberhasilan dari suatu program akan ditandai dengan adanya peningkatan output, sedangkan dari dari segi kualitas dapat dilihat seberapa besar prosentase keberhasilan program yang dilaksanakan.

4. Terlibat dalam evaluasi; bertujuan untuk mengetahui apakah pelaksanaan program telah sesuai dengan rencana yang ditetapkan atau justru ada penyimpangan.

Sementara itu tumbuh dan berkembangnya keterlibatan masyarakat dalam pembangunan, sangat ditentukan oleh tiga unsur pokok yaitu, adanya kesempatan yang diberikan kepada masyarakat untuk dilibatkan, adanya kemauan masyarakat untuk terlibat, dan adanya kemampuan masyarakat untuk berpartisipasi Slamet (dalam Mardikanto dan Soebiato ,2013:91-92). Sedangakn menurut Todaro (2000) dalam konteks pembangunan nasional maupun daerah, "pembangunan yang dilakukan sebagai suatu pembangunan ekonomi, hal tersebut dapat dibenarkan karena pembangunan bukan hanya berarti penekanan pada akselerasi dan peningkatan dalam pertumbuhan perkapita sebagai indeks dari pembangunan, tetapi pembangunan merupakan suatu proses multidimensional yang meliputi pula reorganisasi dan pembaharuan seluruh sistem dan pengembangan sektor 
wisata yang digunakan untuk kepentingan sosial dalam mensejahterakan kehidupanmasyarakat".

Berdasarkanuraian diatas dapat disimpulkan bahwa pembangunan adalah suatu proses yang luas yang menyangkut dimensi sosial, ekonomi, fisik, politik, budaya, wisata dan sebagainya, namun dari dimensi-dimensi tersebut yang paling berpengaruh adalah dimensi ekonomi. Kemajuan ekonomi adalah suatu komponen yang esensial dari pembangunan, walaupun bukan satu-satunya, oleh karena itu pembangunan biasanya diartikan sebagai pembangunan ekonomi, yang didefinisikan sebagai suatu proses yang menyebabkan kesejahteraan penduduk atau masyarakat.

Pariwisata bukanlah fenomena baru di dunia. Menurut Koen Meyers (2009: 104), Pariwisata adalah "aktivitas perjalanan yang dilakukan sementara waktu dari tempat tinggal semula ke daerah tujuan dengan alasan bukan untuk menetap atau mencari nafkah melainkan hanya untuk memenuhi rasa ingin tahu, menghabiskan waktu senggang atau libur dan tujuan-tujuan lainnya". Menurut Sinaga (2010), Pariwisata merupakan "suatu perjalanan yang terencana, yang dilakukan secara individu maupun kelompok dari satu tempat ke tempat lain dengan tujuan untuk mendapatkan suatu bentuk kepuasan dan kesenangan semata". Sedangkan Menurut Hans Buchli (dalam Warpani, 2007 : 6), mendefinisikan bahwa pariwisata adalah "setiap peralihan tempat yang bersifat sementara dari seseorang atau beberapa orang dengan maksud memperoleh pelayanan yang diperuntukkan bagi kepariwisataan itu oleh lembaga-lembaga yang digunakan untuk maksud tetentu".

Menurut Undang Undang No. 10 Tahun 2009 tentang Kepariwisataan, yang dimaksud dengan pariwisata adalah "Berbagai macam kegiatan wisata yang didukung oleh berbagai fasilitas serta layanan yang disediakan masyarakat, pengusaha, Pemerintah dan Pemerintah Daerah'.Pariwisata merupakan sektor yang memberikan kontribusi besar terhadap perekonomian. Untuk dapat membuat menjadikan sektor ini berhasil, maka diperlukan kepandaian dalam mengelola aset pariwisata yang ada, baik aset berbentuk kekayaan alam dan budaya. Keberhasilan kepariwisataan tidak hanya menjadikan target utama menarik wisatawan asing untuk datang, tetapi lebih untuk mengembangkan peluang usaha-usaha masyarakat didalamnya untuk berkembang dan maju, yang bergerak keluar menarik orang luar untuk datang. Usaha-usaha pengembangan pariwisata yang berorientasi pada masyarakat lokal masih kurang.

\section{Metode Penelitian}

Penelitian ini adalah penelitian kualitatif dengan pendekatan deskriptif. Penelitian kualitatif adalah penelitian yang bermaksud untuk memahami fenomena tentang apa yang dialami oleh subjek penelitian secara holistik, dan dengan cara deskripsi dalam bentuk katakata dan bahasa pada suatu konteks khusus yang alamiah dan dengan memanfaatkan berbagai metode alamiah (Moleong, 2011:6).

Penelitian ini dilaksanakan pada masyarakat di pantai lariti Kabupaten Bima.

Sumber data dalam penelitian ini adalah data primer yang merupakan data yang diperoleh dari hasil pengamatan langsung (observasi) dengan pihak-pihak terkait. Dalam hal ini Masyarakat punia kota Mataram yang menggunakan aplikasi gojek.

Untuk mengumpulkan data yang dibutuhkan dalam penulisan ini maka digunakan pengumpulan data sebagai berikut :

1. Penelitian Lapangan (Field Research)

\section{a. Pengamatan (Observasi) \\ b. Wawancara (Interview)}

Teknik analisa data yang digunakan dalam penelitian ini adalah analisis data kualitatif, mengikuti konsep yang diberikan Miles dan Huberman. Miles dan Huberman dan Saldana (2014), mengemukakan bahwa aktifitas dalam analisis data kualitatif dilakukan secara interaktif dan berlangsung secara terus menerus pada setiap tahapan penelitian sehingga sampai tuntas, dan datanya sampai jenuh. Aktivitas dalam analisis data, yaitu data reduction, data display, data reduction, dan conclusion drawing/verification.

\section{Hasil dan Pembahasan}

\section{a. Upaya Pemerintahan Kabupaten Bima Dalam Melibatkan Masyarakat Membangun Wisata Lariti Di Kecamatan Sape Kabupaten Bima}

Masyarakat dalam pembangunan pariwisata menjadi aktor penting, yaitu sebagai pelaksana sekaaligus pengawas dan operasinal pembangunan pariwisata. 
Keterlibatan masayarakat merupakan keikutsertaan dari masyarakat secara sadar dan sukarela dalam proses pembangunan yang meliputi tahap pengambilan keputusan, tahap pelaksanaan kegiatan, tahap pemantauan dan evaluasi pembangunan serta tahap pemanfaatan hasil pembangunan pariwisata.

Keterlibatan masyarakat dalam konteks pembangunan pariwisata di Lariti merupakan hal yang esensial dalam hal pengembangan objek wisata Lariti sebagai eskalasi dan daya tarik untuk menambah antusias wisatawan. Keterlibatan masyarakat berhubungan dengan komponen-komponen pembangunan yang dijalan bersama-sama dengan pemerintah sebagai pengambil kebijakan dan regulasi dengan penuh totalitas. Dalam undang-Undang No. 10 Tahun 2009 tentang pembanunan kepariwisataan menyebutkan segala sesuatu yang memiliki keunikan, keindahan, dan nilai yang berupa keanekaragaman kekayaan alam, budaya serta hasil buatan manusia yang menjadi sasaran atau tujuan kunjungan wisatawan perlu dikembangkan dengan membangun dan menciptakan daya tarik wisatawa. Berimplikasi dari hal tersebut adapun pendapat dari masyarakat Lariti mengenai keterlibatannya dalam pembangunan pariwisata pada objek wisata Lariti, seperti salah satu pendapat dari Ibu Hadijah yang menuturkan pendapatnya mengenai keterlibatan masyarakat dalam pembangunan pariwisata Lariti :

"Menurut saya, bentuk keterlibatan kami sebagai masyarakat yang ada disekitar wisata Lariti adalah selalu menjaga keamanan dan kebersihan wisata lariti sehingga wisatawan yang datang berkunjung ke wisata lariti merasa nyaman dengan suasana yang ada di Lariti." (Hasil Wawancara, Ibu Hadijah, Kamis, 03 April 2018).Dalam hal ini keterlibatan masyarakat disekitar lariti sangat baik sekali karena masyarakat terlibat ikut terlibat dalam mengelola wisata lariti.

Selanjutnya dengan pendapat yang tidak jauh berbeda disampaikan oleh Bapak Sulaiman, mengenai keterlibatan dari masyarakat terhadap pembangunan pariwisata di Lariti :

"Menurut saya, bentuk keterlibatan kami sebagai masyarakat adalah membantu pemerintah dalam membangun dan menjaga wisata Larti." (Hasil Wawancara, Bapak Sulaiman, Sabtu, 05 April 2018). Sementara menurut Ibu Nurul selaku wisatawan Lariti :

"Menurut saya, kami sebagai wisatawan lariti sangat senang dan terbantu sekali, masyarakat lariti sangat kreatif,aktif dalam membangun dan menjaga wisata lariti serta dengan adanya keterlibatan langsung masyarakat wisata lariti kedepannya bisa berkembang dan lebih dikenal lagi oleh publik." (Hasil wawancara Ibu Nurul, Sabtu 05 April 2018).

Berdasarkan dari uraian pendapat yang disampaikan oleh masyarakat dan wisatawan mengenai keterlibatan masyarakat dalam pembangunan objek wisata Lariti dapat dilihat bahwa keterlibatan masyarakat pada kawasan Lariti dalam hal pembangunan wisata yaitu menjaga dan melesatarikan potensi yang ada untuk tetap alami dan tetap menjadi daya tarik wisatawan. Dengan pendapat serupa juga dikemukakan oleh Bapak haris, salah satu masyarakat dikawasan objek wisata Lariti, menurutnya : "Menurut saya, masyarakat sudah terlibat langsung dalam membangun wisata Lariti, bentuk keterlibatan masyarakat adalah masyarakat menampilkan sebuah kreatifitas seperti, membuat masakan tradisional sehingga wisatawan tertarik mengunjunginya." (Hasil Wawancara Bapak haris, Minggu, 06 April 2018).

Dari pendapat tersebut dapat dilihat bentuk keterlibatan masyarakat dalam pembangunan objek wisata Lariti yaitu dengan cara menarik perhatian wisatawan melalui kreatifitas seperti, membuat masakan tradisional. Pada sisi yang berbeda menanggapi pendapat yang disampaikan oleh masyarakat mengenai keterlibatan masyarakat dalam pembangunan wisata Lariti, Bapak Muhammad Akbar SP, M.Si, selaku Kabid Pengembangan Dinas Pariwisata Kabupaten Bima menyampaikan : "Masyarakat yang ada disekitar wisata lariti sangat aktif dalam mengelola dan menjaga lingkungan, karena wisata lariti termasuk destinasi pariwisata yang memiliki keunikan, salah satunya pantai yang bisa terbelah dua." (Hasil Wawancara, Bapak Muhammad Akbar SP, M.Si, Senin, 15 April 2018). 
Dengan pendapat yang sama Drs. Dahlan, selaku Kepala Dinas Pariwisata Kabupaten Bima memperjelas tentang keterlibatan masyarakat dalam membangun wisata Lariti, yaitu :

"Masyarakat yang terjun langsung dalam membangun dan mengembangkan wisata lariti, pemerintah hanya mengarahkan dan memberikan bantuan sehingga wisata lariti kedepannya lebih dikenal oleh publik." (Hasil Wawancara, Drs. Dahlan, Senin, 16 April 2018).

Dari pendapat diatas menunjukan bahwa keterlibatan masyarakat secara aktif dan sadar dilakukan oleh masyarakat dengan cara mengelola dan menjaga lingkungan yang menjadi destinasi wisata dengan cara mempromosikan keanekaragaman dan keunikan dari Lariti. Destinasi wisata sebagai area dan kawasan yang menjadi tujuan wisatawan untuk mengexplore keindahan dan keunikan yang dimiliki oleh suatu tempat, keterlibatan masyarakat dalam aspek pembangunan pariwisata pada suatu daerah yang menjadi kawasan wisata seperti Lariti, berperan penting untuk mendukung kemajuan serta pengembangan yang ada.

Berdasarkan hasil wawancara menunjukan bahwa masyarakat terlibat secara aktif dalam pembangunan pariwisata yang ada di Lariti, yaitu dengan cara menjaga dan melestarikan Lariti sebagai destinasi wisata yang menjadi tujuan dari wisatawan. Dikatakan masyarakat terlibat aktif karena sesuai dengan pernyataan menurut Fandeli (2002:56) yang menyatakan bahwa keterlibatan masyarakat dengan sadar ikut terlibat dalam pembangunan pariwisata secara tidak langsung artinya membantu kegiatan pemerintah memajukan sektor pariwisata.

Menurut Spillane dalam Gayatri (2005:77) keterlibatan masyarakat dalam pembangunan wisata adalah tindakan terstruktur yang dilaksanakan oleh instrumen masa melalui kegiatan pelestarian, pemfasilitasan, dan promositasi. Hal ini sesuai dengan keadaan pantai lariti yang masih terjaga dengan baik dan memiliki fasilitas yang memadai, dan mempermudah wisatawan dalam mengakses tempat wisata. Dengan keadaan demikian, masyarakat yang ada di pantai Lariti dapat dikatakan terlibat aktif dikarenakan masyarakat melestarikan lingkungan sekitar pantai, memberikan fasilitas yang cukup bagi wisatawan, dan sekaligus mempromosikan tempat wisata yang ada di Lariti baik melalui media sosial maupun secara langsung ke masyarakat luar.

$$
\text { Upaya pemerintah dalam }
$$

pembangunan pariwisata merupakan hal yang berperan penting sebagai langkah untuk meratakan pembangunan wisata dan pemanfaatan obyek wisata untuk kepentingan bersama. Pemerintah memiliki andil besar dalam pembangunan khususnya pembangunan sektor wisata yaitu dengan memanfaatkan secara keseluruhan ketersedian pariwisata dengan cara menjaga dan melestarikan serta mengembangkan objek pariwisata, Fandeli (2002:91). Pariwisata merupakan salah satu sektor strategis nasional sebagai instrumen pendekatan kemajuan pembangunan dan peningkatan kesejahteraan, artinya dengan pariwisata peningkatan kesejahteraan masyarakat dapat terlaksana.

Upaya pemerintah dalam pembangunan wisata Lariti secara jelas merupakan tugas dan tanggug jawab dari Dinas Pariwisata dan Kebudayaan Kabupaten Bima, dalam kaitan perwujudan kesejahteraan rakyat melalui pembangunan pariwisata dapat terlaksana apabila Pemerintah Kabupaten Bima melalui Dinas Pariwisata dan Kebudayaan secara sungguhsungguh dan nyata membangun atau mengembangkan Lariti sebagai sektor wisata. Adapun pendapat masyarakat tentang upaya pemerintah Kabupaten Bima dalam membangun wisata Lariti, salah satunya seperti penyampaian dari Ibu Aini yang merupakan masyarakat kawasan wisata Lariti :

"Menurut saya, Upaya pemerintah dalam membangun wisata Lariti sudah bagus, Pemerintah sudah memberikan pelayanan, ilmu pengetahuan tentang kepariwisataan sehingga sumber daya ekonomi kami sebagai masyarakat yang ada disekitar wisata Lariti jauh lebih baik." (Hasil Wawancara, Ibu Aini, Kamis, 03 April 2018).

Hal ini senada dengan yang disampaikan oleh Bapak Abdullah selaku penjaga pantai wisata lariti mengenai upaya 
pemerintah dalam pembangunan wisata Lariti, menurutnya :

"Menurut saya, Pemerintah selama ini sudah mendampingi dan memberikan perananan penting kepada komunitas atau kelompok serta mengadakan sosisalisasi kepada masyarakat yang membangun sumber daya masyarakat yang ada disekitar wisata Lariti." (Hasil Wawancara,Bapak Abdullah, Sabtu, 05 April 2018).

Dari uraian pendapat yang disampaikan oleh masyarakat yang berada dikawasan objek wisata Lariti dapat dilihat bahwa upaya pemerintah dalam pembangunan wisata yang ada di Lariti melalui pelaksanan sosialisasi kepada masyarakat untuk pembentukan kelompok atau komunitas Lariti. Masih dengan pendapat serupa disampaikan oleh Bapak Haris terhadap upaya yang dilakukan pemerintah dalam pembangunan pariwisata Lariti yakni :

"Menurut saya, Upaya pemerintah dalam membangun wisata Lariti sudah cukup bagus karena, pemerintah selalu memberikan program-program seperti, mengadakan festival-festival di wisata Lariti sehingga wisatawan tertarik untuk mengunjungi wisata Lariti dan membangun sember daya masyarakat yang ada disekitar lariti." (Hasil Wawancara Bapak Haris, Minggu, 06 April 2018).

Dari pendapat yang disampaikan oleh salah satu masyarakat Lariti dapat dilihat upaya pemerintah dalam pembangunan objek wisata Lariti dengan program serta pengadaan even atau festifal untuk menarik minat dan menjadi daya tarik wisatawan. Disisi lain menanggapi pendapat masyarakat mengenai upaya pemerintah dalam pembangunan objek wisata Lariti disampaikan oleh Bapak Muhammad Akbar SP, M.Si selaku Kabid Pengembangan Dinas Pariwisata Kabupaten Bima :

"Menurut saya, Pemerintah selalu memberikan arahan dan menambah ilmu pengetahuan tentang sektor kepariwisatan dan memperbaiki akses jalan, sehingga mempermudah wisatawan berkunjung ke wisata Lariti." (Hasil Wawancara, Bapak Muhammad Akbar SP, M.Si, Senin, 15 April 2018).
Dengan pendapat yang sama turut disampaiakan Bapak Drs. Dahlan mengenai upaya pemerintah dalam pembangunan wisata Lariti, menurutnya :

"Ada beberapa upaya yang dilakukan oleh pemerintah terkait dengan pemberdayaan masyarakat tentang sektor kepariwisatan, bukan hanya pembangunan secara fisik akan tetapi pembangunan secara mental juga sering dilakukan oleh pemerintah dan pendekatan-pendekatan terhadap komunitas yang konsen dibidang kepariwisataan, kemudian kelompok cadar wisata. Tanpa melibatkan masyarakat dalam membangun kepariwisataan dan upaya pemerintah dalam membangun destinasi wisata sangatlah sulit." (Hasil Wawancara, Bapak Drs. Dahlan, Senin, 16 April 2018).

Berdasarkan dari tanggapan mengenai upaya pemerintah dalam pembangunan pariwisata Lariti menunjukan bahwa pemerintah dalam hal ini Dinas Pariwisata dan Kebudayaan Kabupaten Bima melakukan pembangunan secara fisik, pembangunan mental dengan pendekatan persuasif untuk mengajak masyarakat bersama-sama terlibat.

Lariti sebagai objek dan destinasi wisata dengan pengelolaan serta upaya pemerintah untuk membangun pariwisata berpotensi meningkatkan aspek kesejahteraan pada masyarakat sekitar. Dalam pembangunan sektor wisata oleh Pemerintah Kabupaten Bima diatur dalam Perda Nomor 4 Tahun 2015 tentang Rencana pengembangan Lariti sebagai kawasan pariwisata yaitu dengan program kegiatan berdasarkan waktu pelaksanan (jangka panjang) dan (jangka pendek), adapun rencana jangka panjag seperti, Rencana Wisata dan Event, Kolaborasi Wisata Dengan Usaha Perikanan, sedangkan rencana jangka pendek seperti, Rencana Infrastruktur, Rencana Fasilitas Penunjang, dan Rencana Pengembangan.

Menurut Damanik dan Weber (2006:88), upaya pemerintah untuk pembangunan wisata merupakan pelaksanaan dari program kegitan yang telah ditetapkan dalam rangka memberikan akses serta kemudahan untuk wisatawan. Sementara menurut Sunaryo selaku ketua Komunitas Lariti upaya pemerintah dalam pembangunan pariwisata yaitu penerapan 
pembangunan sarana dan prasarana dan usaha meningkatkan minat wisatawan.

Berdasarkan dari hasil wawancara dapat dikatakan bahwa Pemerintah Kabupaten Bima, telah berupaya membangun pariwisata dengan cara sosialisasi persuasif yang dimana pemerintah kabupaten memberikan arahan dan pengetahuan dalam bentuk sosilisasi kepariwisataan serta mengadakan festival yang mampu menarik wisatawan berkunjung ke Lariti. Selain itu pembangunan fisik yang dilakukan oleh pemerintah berupa akses jalan yang memadai fasilitas yang disediakan di tempat wisata serta pembangunan mental yang yang dilakukan melalui pendekatan emosional masyarakat dan komunitas yang berfokus pada pariwisata guna membina masyarakat, dikarenakan masyarakat terlibat secara langsung dalam pengembangan dan pembangunan pariwisata.

Kawasan wisata adalah suatu kawasan yang mempunyai luas tertentu yang sengaja dibangun dan disediakan untuk kegiatan pariwisata atau jasa wisata atau tempat yang memiliki sumber daya wisata yang dibangun dan dikembangkan sehingga mempunyai daya tarik dan diusahakan sebagai tempat yang dikunjungi wisatawan. Lariti sebagai salah satu objek wisata yang sedang dikembangkan dan dibangun sangat potensial sebagai salah satu sarana untuk meningkatkan kesejahteraaan masyarakat melalui sektor yang bergerak dibidang wisata.

Berdasarkan dari keseluruhan wawancara diatas, hasil penelitian Upaya Pemerintah Kabupaten Bima Dalam Melibatkan Masyarakat Membangun Wisata Lariti di Kecamatan Sape berada pada nilai positif, hal ini menunjukan bahwa secara kualitatif Pemerintah Kabupaten Bima melalui Dinas Pariwisata dan Kebudayaan Kabupaten Bima melibatkan masyarakat secara aktif dalam membangun wisata Lariti dan dalam proses mapun pelaksaanannya pembangunan wisata Lariti dipengaruhi oleh infrastruktur dan kebijakan pembangunan yang belum maksimal sebagai faktor penghambat dengan perilaku masyarakat berupa sikap keterbukaan menerima wisatawan dengan sopan dan ramah sebagai faktor pendukung. Dalam hal ini pemerintah mengadakan sosialisasi yang melibatkan langsung masyarakat dan komunitaskomunitas yang ada di lariti.

\section{Simpulan}

Dari penelitian dan pembahasan yang telah penulis uraikan pada bab sebelumnya, adapun kesimpulan yang dapat ditarik yakni :

1. Upaya Pemerintah Kabupaten Bima dalam melibatkan masyarakat untuk membangun wisata Lariti yakni :

a. Strategi yang dilakukan oleh pemerintah dalam pembangunan dan pengembangan wisata lariti sudah sangat baik, dalam hal ini pemerintah sudah menyiapakan program-program yang bisa meningkatkan daya tarik wisatawan.

2. Pemerintah Kabupaten Bima telah melibatkan masyarakat dalam pembangunan wisata Lariti, hal ini menunjukan masyarakat secara aktif ikut melaksanakan pembanguan pariwisata di Lariti besama dengan Pemerintah Kabupaten Bima.

3. Faktor pendukung dalam upaya Pemerintah melibatkan masyarakat untuk membangun wisata Lariti yaitu,

a. Pelayanan masyarakat yang sangat baik.

b. Letak kawasan wisata Lariti yang sangat strategis.

c. Keterlibatan masyarakat dalam menjaga dan mengelola wisata lariti yang sangat bagus .

4. Faktor penghambat dalam upaya Pemerintah melibatkan masyarakat untuk membangun wisata Lariti adalah sebagai berikut :

Menurut Pemerintah Kabupaten Bima yaitu :

a. Minimnya kesadaran masyarakat tentang kepariwisataan.

b. Peraturan pemerintah daerah yang telah ditetapkan tidak berjalan secara sempurna. Menurut Wisatawan yaitu :

a. Infrastuktur berupa jalan yang belum sepenuhnya bagus.

b. Pembangunan kawasan sekitar Lariti belum efektif.

Menurut Masyarakat yaitu :

a. Minimnya sumber air bersih dan bantuan dari pemerintah yang belum merata.

b. Tingkat kesadaran masyarakat yang belum efektif.

Saran 
Adapun beberapa saran yang dapat penulis rumuskan sebagai masukan untuk Pemerintah Kabupaten Bima dalam pembangunan wisata Lariti diantaranya sebagai berikut :

1. Meningkatkan sosialisasi kepada masyarakat sebagai upaya untuk menciptakan kesadaran terhadap pentingnya keberadaan wisata Lariti untuk dijaga bersama-sama dan dilestarikan.

2. Peningkatan promosi Lariti melalui media sosial secara intens untuk menjaring animo wisatawan dalam jumlah besar dengan memperlihatkan keunikan serta keunggulan yang dimiliki Lariti dengan objek wisata lain.

3.Perbaikan dan penyediaan infrastruktur berupa sarana jalan yang memadai untuk memudahkan mobilitas wisatawan berkunjung ke Lariti.

4. Memberi kemudahan pihak swasta untuk berinfestasi di kawasan Lariti untuk mendorong percepatan pembangunan sekaligus pengembangan wisata Lariti.

5.Pengadaan event dan festisal budaya bersekala besar untuk mengiklankan Lariti pada wisatawan baik wisatawan domestik maupun wisatawan mancanegara.

6. Pada pemerintah untuk melibatkan masyarakat Sape, khususnya masyarakat sekitar pantai Lariti dalam pengelolaan pantai dan sebagai pelaku usaha disekitar pantai Lariti

\section{DAFTAR PUSTAKA}

[1] Ach. Wazir Ws., et al., ed. (1999). Panduan Penguatan Menejemen Lembaga Swadaya Masyarakat. Jakarta: Sekretariat Bina Desa dengan dukungan AusAID melalui Indonesia HIV/AIDS and STD Prevention and Care Project.

[2] Conyers, Diana. (1991). Perencanaan Sosial di Dunia ketiga. Yogyakarta: UGM Press.

[3] Damanik dan Weber. 2006. Perencanaan Ekowisata dan Teori ke Aplikasi. Yogyakarta: Penerbit Andi

[4] Dwiningrum, S.I.A. 2011. Desentralisasi dan Keterlibatan Masyarakat dalam Pariwisata. Yogyakarta: Pustaka Pelajar.
[5] Fandeli, C. 2002. Perencanaan Kepariwisataan Alam. Yogyakarta: Fakultas Kehutanan Univertisa Gajah Mada.

[6] Gayatri. 2005. Sosiologi Pariwisata. Yogyakarta: Penerbit Andi. Poloma.

[7] Hadinoto, Kusudianto. 1996. Perencanaan Pengembangan Destinasi Pariwisata. Jakarta: UI-Press.

[8] Holil Soelaiman. (1980). Partisipasi Sosial dalam Usaha Kesejahteraan Sosial. Bandung.

[9] Isbandi Rukminto Adi. (2007). Perencanaan Partisipatoris Berbasis Aset Komunitas: dari Pemikiran Menuju Penerapan. Depok: FISIP UI Press.

[10]Karyono, A. H. (1997). Kepariwisataan. Jakarta: Gramedia Widiasarana.

[11]Linton. 2002. Penerapan Pembangunan Wisata Alam. PT. Rineka Cipta : Jakarta

[12]Marpaung. 2002. Strategi Pembanguan Sektor Wisata. Graha Pustaka: Yogyakarta

[13] Mikkelsen, Britha. (1999). Metode Penelitian Partisipatoris dan Upaya-upaya Pemberdayaan: sebuah buku pegangan bagi para praktisi lapangan. Jakarta: Yayasan Obor Indonesia.

[14]Pendit, N S. 1999. Ilmu Pariwisata: Sebuah Pengantar Perdana. Jakarta: Pradnya Paramita.

[15]Peraturan Mentri Pariwisata No 8 Tahun 2017 ) tentang pendapatan Nasional dan pendapatan Daerah

[16] Peraturan Mentri Pariwisata Tahun 2015 No 545 tentang luas wilayah perairan Indonesia.

[17]Pitana, I G. Diarta, S. 2009. Pengantar Ilmu Pariwisata. Yogyakarta: Penerbit Andi. Pitana, I G.

[18]Pitana, I Gde., and I Ketut Surya Diarta. 2009. Pengantar ilmu pariwisata. Yogyakarta: Andi.

[19]Ross, Murray G., and B.W. Lappin. (1967). Community Organization: theory, principles and practice. Second Edition. NewYork: Harper \& Row Publishers.

[20] Sugiyono, Prof. Dr. 2016. Metode Penelitian Kuantitatif dan Kualitatif, Cetakan ke-20. Bandung: Alfabeta,cv 
[21] Sumampouw, Monique. (2004). "Perencanaan Darat-Laut yang Terintegrasi dengan Menggunakan Informasi Spasial yang Partisipatif." Jacub Rais, et al. Menata Ruang Laut Terpadu. Jakarta: Pradnya Paramita. 91117.

[22] Sunaryo, Bambang. 2013. Kebijakan Pembangunan Destinasi Pariwisata. Yogyakarta: Gava Media.

[23] T.Soebiato, P. 2013. Pemberdayaan Masyarakat dalam kebijakan Publik. Bandung: Alfabeta.

[24] Tjokroamidjojo, B. 1998. Teori dan StrategiPembangunan Nasional. Jakarta: CV. Haji Mas Agung.

[25] Undang-undang RI Nomor 10 Tahun 2009 tentang kepariwisataan. 